\title{
Małoinwazyjne metody w leczeniu przewlekłych dolegliwości bólowych kręgosłupa - udział pielęgniarki w zwalczaniu bólu
}

\author{
Minimally -invasive methods for the treatment of chronic spinal pain - \\ participation of the nurse in fighting pain
}

\author{
ANNA RASZKA ${ }^{1,3}$, AGNIESZKA KRÓLIKOWSKA , ANNA ANTCZAK-KOMOTERSKA ${ }^{2,3}$ \\ 110 Wojskowy Szpital Kliniczny z Polikliniką w Bydgoszczy \\ 2 Państwowa Wyższa Szkoła Zawodowa we Włocławku, Instytut Nauk o Zdrowiu \\ ${ }^{3}$ Zakład Pielęgniarstwa Neurologicznego i Neurochirurgicznego CM w Bydgoszczy UMK \\ w Toruniu, Studia doktoranckie
}

DOI: http://dx.doi.org/10.21784/IwP.2017.018

ISSN: $2451-1846$

\section{Streszczenie:}

Przewlekłe zespoły bólowe kręgosłupa w znacznej części wynikają ze zmian przeciążeniowo-zwyrodnieniowych. Przyczyną powstałego procesu są zarówno uwarunkowania genetyczne, anatomiczne jak również cywilizacyjne. Występowanie dolegliwości bólowych ma tendencje do zwiększania się szczególnie u osób w 4 i 5 dekadzie życia będąc jednocześnie najczęstszą przyczyną bólu kręgosłupa. Powstały proces patologicznych zmian w obrębie kręgosłupa ma charakter postępujący, jest przyczyną występowania zaburzeń zarówno w sferze fizjologicznej, psychologicznej jak i społecznej powodując zmniejszenie wydolności funkcjonalnej pacjentów, wycofanie się z pełnionych do tej pory ról społecznych i poczucie bezradności w postępującym bólu. Przewlekłe zespoły bólowe kręgosłupa lędźwiowego powstałe na tle zmian przeciążeniowo-zwyrodnieniowych są wskazaniem do zastosowania małoinwazyjnych procedur neurochirurgicznych, dzięki którym można uzyskać poprawę komfortu oraz wydolności funkcjonalnej pacjentów.

Artykuł ma na celu przedstawienie leczenia przewlekłych zespołów bólowych za pomocą termolezji lędźwiowej jako skutecznej metody mającej wpływ na zmniejszenie tych przykrych dolegliwości jakimi są bóle kręgosłupa oraz udziału pielęgniarki w zwalczaniu dolegliwości bólowych.

Słowa kluczowe: termolezja, kręgosłup lędźwiowy, ból, pielęgniarka, opieka

\section{Abstract:}

Chronic spine pain syndromes most often result from strain-degenerative changes. They are caused by genetic factors, anatomic condition as well as civilization changes. Pain is more severe among people in 4th and 5th decade of life and is the most frequent cause of spinal pain. Pathological changes in the spine result in physiological, psychological and social disorders leading to reduced funcional capacity of patients, withdrawal from social roles and the feeling of 
helplessness in pain. Chronic pain syndromes of the lumbar spine relating to strain-degenerative changes indicate the application of minimally -invasive neurosurgical procedures, which will make it possible to improve patients' comfort and funcional capacity.

The article aims to disucss the teratment of chronic pain syndromes with the help of lumbar thermocoagulation as the effective method in reducing spinal pain together with nursing intervention in pain relief.

Key Words: thermocoagulation, lumbar spine, pain, nursing care

\section{Wstęp}

Przewlekłe dolegliwości bólowe kręgosłupa w większości przypadków spowodowane są zmianami zwyrodnieniowymi i przeciążeniowymi, na które mają wpływ uwarunkowania cywilizacyjne, czynniki genetyczne, styl życia, typ budowy kręgosłupa czy też właściwości tkanki łącznej. Kręgosłup człowieka jako centralna oś ciała pełni funkcję podporową. Krążki międzykręgowe pracują nieustannie wykonując największą pracę w pozycji siedzącej i stojącej, gdzie dźwigają masę tułowia, głowy, kończyn górnych jakże często pomnożone przez niewłaściwie podnoszone ciężary.

Nieustanna praca jaką wykonuje kręgosłup powoduje, iż krążek międzykręgowy poddawany jest ciągłym naciskom, obciążeniom i urazom działającym na różnych płaszczyznach, pod wpływem których ulega on ciągłej degeneracji, zmniejszeniu ulega jego uwodnienie, co $\mathrm{w}$ konsekwencji powoduje zaburzenia $\mathrm{w}$ prawidłowym jego funkcjonowaniu prowadząc do zmian zwyrodnieniowych.

Zbliżając się do podstawy kręgosłupa obciążenia mają tendencje do zwiększania się powodując największą ich kumulację w dolnym jego odcinku. Dotknięty procesem zmian przeciążeniowo-zwyrodnieniowych kręgosłup lędźwiowy jest jednym z najczęstszych źródeł bólu [1-3]. Kumulacja szeregu mikrourazów i ciągłych obciążeń skutkuje tym, iż powstały proces ma najczęściej charakter postępujący doprowadzając do szeregu zmian patologicznych. Anatomiczne struktury składowe kręgosłupa a przede wszystkim tylny schemat kręgowy są bardzo bogato unerwione, więc jakiekolwiek patologiczne zmiany powodują podrażnienie receptorów nocyceptywnych zakończeń nerwowych a tym samym wystąpienie szeregu objawów takich jak dolegliwości bólowe, deficyty neurologiczne np. mrowienia, drętwienia, zaburzenia czucia [4,5].

Nawroty dolegliwości bólowych i jakże olbrzymia kaskada związanych z nim negatywnych skutków przyczynia się do pogorszenia wydolności organizmu, wystąpienia deficytów w zakresie samoopieki i samopielęgnacji, a w konsekwencji do niepełnej sprawności, ograniczenia wydolności funkcjonalnej i pełnienia ról społecznych. Zazwyczaj początkowym etapem terapii bólu kręgosłupa jest leczenie zachowawcze mające na celu złagodzenie dolegliwości oraz zminimalizowanie dyskomfortu, które zazwyczaj jest skuteczne tylko przez pewien okres czasu [6,7].

Ze względu na duże cierpienie i zmiany dotyczące wszystkich aspektów życia pacjentów z bólem przewlekłym, ból taki wymaga kompleksowego i wielokierunkowego postępowania. W przypadku braku poprawy leczenia zachowawczego (farmakoterapia, 
fizykoterapia) wiążącego się z niemożnością codziennego funkcjonowania rozważa się ewentualność zastosowania procedur neurochirurgicznych [8,9].

W przypadku, gdy występują przeciwwskazania do wykonania klasycznego zabiegu neurochirurgicznego lub nie ma wystarczających wskazań do jego wykonania rozważa się wykonanie małoinwazyjnych i nowoczesnych metod zwalczania przewlekłego bólu kręgosłupa jakimi są zabiegi termolezji. Wskazaniem do jej zastosowania są przewlekłe dolegliwości bólowe kręgosłupa w przebiegu zmian przeciążeniowozwyrodnieniowych stawów międzywyrostkowych kręgosłupa.

\section{Przegląd literatury}

Nawracające, uporczywe i przewlekłe dolegliwości bólowe kręgosłupa są problemem XXI wieku. Dolegliwości dotyczą sporej części osób w wieku produkcyjnym. Częstość występowania tych dolegliwości wzrasta u ludzi po 40 roku życia. Na podstawie badań socjodemograficznych stwierdzono, iż na przewlekły zespół bólowy kręgosłupa cierpi 38-74\% mężczyzn oraz 14-23\% kobiet. Mechanizmy powstawania bólu przewlekłego są przyczyną wystąpienia szeregu objawów somatycznych oraz problemów zarówno na płaszczyźnie fizjologicznej, psychologicznej jak i społecznej powodując przewlekłe dolegliwości bólowe kręgosłupa oraz obniżenie wydolności funkcjonalnej pacjentów [10-12]. Podejmując działania w zakresie zwalczania przewlekłych dolegliwości bólowych kręgosłupa lędźwiowego trzeba mieć na uwadze szerokie i wieloaspektowe postępowanie zarówno na etapie leczenia zachowawczego, psychoterapii czy programów rehabilitacyjnych ale również nowoczesnych technik. Zastosowanie termolezji jest małoinwazyjną i skuteczną metodą zwalczania dolegliwości bólowych kręgosłupa.

Przeprowadzone badania w latach 2009-2011roku w Poradni Leczenia Bólu w Warszawie potwierdziły skuteczność zabiegu termolezji jako metody leczenia bólu przewlekłego. Pozytywny efekt zabiegu zaobserwowano u zdecydowanej większości badanych pacjentów. Na podstawie analizy piśmiennictwa wywnioskowano, iż poprawnie zastosowana technika zabiegu termolezji lędźwiowej ma przewagę nad innymi metodami neurodestrukcji stosowanymi w zwalczaniu dolegliwości bólowych [13].

Pozytywne wyniki zabiegu termolezji uzyskano również u pacjentów z dolegliwościami bólowymi kręgosłupa w odcinku szyjnym oraz piersiowym, u których miejscem powstawania dolegliwości są zmiany zwyrodnieniowe stawów międzywyrostkowych kręgosłupa.

Wstępne badania, które przeprowadzono w Klinice Neurochirurgii w 10 Wojskowym Szpitalu Klinicznym z Polikliniką w Bydgoszczy w 2015 roku obejmowały 30 osobową grupę pacjentów zakwalifikowanych do zabiegu termolezji stawów międzykręgowych w odcinku lędźwiowym. U badanych respondentów oceniano poziom odczuwanych dolegliwości bólowych z użyciem skali analogowo-wzrokowej VAS (Visual Analogue Scale) oraz jakość życia za pomocą kwestionariusza niesprawności Oswestry 
Disability Questionaire (ODQ) w okresie przed zabiegiem oraz w pierwszym dniu po zabiegu, po pierwszym miesiącu, trzech miesiącach i po pół roku [14].

$\mathrm{Na}$ podstawie analizy przeprowadzonych badań stwierdzono zmniejszenie nasilenia odczuwanego bólu i niesprawności utrzymujące się zarówno w okresie wczesnym jak i późnym po wykonanym zabiegu termolezji lędźwiowej. Wywnioskowano, iż termolezja lędźwiowa jest skuteczną metodą leczenia bólu lędźwiowego pochodzenia stawowego oraz zmniejsza niepełnosprawność pacjentów w okresie wczesnym oraz późnym.

Według analizy piśmiennictwa ta małoinwazyjna metoda charakteryzuje się wysoką skutecznością (ok.70\%) u większości leczonych pacjentów. Zabiegi neurodestrukcyjne mają również szerokie zastosowanie w leczeniu skojarzonym u chorych z bólem neuropatycznym. Wielokierunkowa terapia u chorych z przewlekłymi dolegliwościami bólowymi, o której wspomina J. Dobrogowski nawiązuje do konieczności oraz skuteczności stosowania zarówno programów rehabilitacyjnych jaki i metod neurodestrukcyjnych, których celem jest redukcja przykrych doznań bólowych i jakże oczekiwana przez pacjentów poprawa jakości życia [15-17].

Badania kliniczne, których celem była ocena skuteczności zabiegu termolezji wykonywanej $\mathrm{u}$ pacjentów $\mathrm{z}$ neuralgią nerwu trójdzielnego opornych na leczenie farmakologiczne dowiodły, iż u 72,31\% badanych efekt leczenia był dobry i bardzo dobry, natomiast u pozostałych chorych nie udało się uzyskać zmniejszenia dolegliwości [18].

Bardzo dobre efekty leczenia metodą termolezji zaobserwowano w obserwacjach przeprowadzonych przez Ruiz-Lopez i Erdine. Autorzy opisali skuteczność zabiegu termolezji u zdecydowanej większości leczonych. 98\% pacjentów odczuło zmniejszenie dolegliwości bólowych. Nawroty dolegliwości zaobserwowano u $15 \%$ pacjentów po upływie 5 lat natomiast u $20 \%$ po 9 latach od wykonania zabiegu [19].

Zabiegi termolezji znalazły szerokie zastosowanie również u pacjentów z zespołami bólowymi głowy. Zauważono również pozytywne wyniki terapii oraz zmniejszenie dolegliwości w przypadku neuralgii nerwu trójdzielnego. Długotrwały efekt leczenia neuralgii nerwu trójdzielnego za pomocą małoinwazyjnej metody jaką jest termolezja zaobserwowano $\mathrm{w}$ badaniach przeprowadzonych przez Yoon i wsp. Skuteczność odległych wyników potwierdzono u osób, których nie poddawano innym procedurom inwazyjnym [20].

Realizując proces pielęgnowania wobec pacjenta z zespołem bólowym kręgosłupa w okresie okołooperacyjnym rola pielęgniarki jest znacząca ponieważ spędzając najwięcej czasu przy chorym mają możliwość zarówno prowadzenia wnikliwej obserwacji, jak również podejmowania skutecznych działań mających na celu rozpoznanie i zmniejszenie dolegliwości. Opiekując się pacjentem z zespołem bólowym należy pamiętać, że ból będąc subiektywnym doznaniem jest trudnym parametrem od oceny. Dla jednego pacjenta pewien poziom odczuwanego bólu może być odbierany przez innego pacjenta jako ból nie do zniesienia. Bardzo ważna w tym czasie jest czujność, identyfikacja pacjenta cierpiącego oraz obserwacja jego stanu, a czego brak może przyczynić się do przeoczenia 
niepokojących dolegliwości i objawów, co w konsekwencji łączy się z nieodwracalnymi negatywnymi skutkami zarówno dla zdrowia jak i życia pacjenta.

Wnikliwa i dokładna obserwacja ( również pozawerbalna) jest pomocna w rozpoznawaniu bólu np. u pacjentów nieśmiałych, zamkniętych w sobie i przygnębionych nową sytuacją, tych którzy niechętnie dzielą się swoimi odczuciami.

Najważniejszym a jednocześnie podstawowym elementem zwalczania bólu jest jego dokładny pomiar zarówno w spoczynku jak i podczas wykonywania czynności ruchowych za pomocą znanych i dostępnych skal oraz konieczność prowadzenia dokumentacji tego parametru, który jako piąty parametr życiowy zasługuje na uwagę.

Dzięki doskonałej współpracy całego zespołu terapeutycznego możliwe staje się całkowite wyeliminowanie bólu $\mathrm{w}$ okresie okołooperacyjnym $\mathrm{z}$ wykorzystaniem aktualnego stanu wiedzy, dostępnych metod oraz leków przeciwbólowych.

Podejmowanie tych czynności jest nierozłącznym elementem procesu terapeutycznego ponieważ nie możemy mówić o skutecznym uśmierzaniu bólu, jeżeli nie kontrolujemy jego natężenia czy też zmian tego parametru pod wpływem podawanych leków lub zastosowania innych działań terapeutycznych. Kontrola stopnia natężenia odczuwanego bólu przez pacjenta oraz efekt działania przeciwbólowego powinien odbywać przez całą dobę natomiast ocena natężenia bólu w tym okresie powinna obejmować również reakcję pacjenta na zaleconą terapię.

Prowadzenie przez pielęgniarkę dokładnej i zwięzłej dokumentacji leczenia bólu (Pain Management Documentation - PMD) jest zasadniczym elementem podejmowanych zadań wobec pacjenta i w wielu wypadkach jest jedyny obiektywnym miernikiem udzielonych mu świadczeń medycznych. Stanowi bowiem kluczowy wskaźnik w zapewnieniu wysokiej jakości opieki szczególnie w okresie okołooperacyjnym. Dokumentacja leczenia bólu jest bardzo użyteczny narzędziem koniecznym do wzajemnego komunikowania się lekarzy i pielęgniarek między sobą, którego celem jest zapewnienie ciągłości leczenia oraz zindywidualizowanie terapii wobec pacjenta i wykorzystanie uzyskanych informacji z pomiarów w procesie leczenia.

Udział pielęgniarki w farmakoterapii jest również istotny w okresie okołooperacyjnym. Ponieważ ból nieprawidłowo leczony jest przyczyną wielu powikłań pooperacyjnych i przedłużenia się pobytu pacjenta w szpitalu a tym samym dłuższego powrotu do zdrowia oraz obniżenia jakości jego życia. Zalecane leki powinny być podawane zgodnie z pisemnym zleceniem lekarskim $\mathrm{w}$ odpowiednich i regularnych odstępach czasu, gdzie dawka leku jest indywidualnie dobrana i dostosowana do stopnia natężenia bólu, a które wystarczyłyby żeby zapewnić możliwie najdłuższy okres bezbólowy [21,22]. Edukacja pacjenta w okresie okołooperacyjnym przyczyni się do redukcji stresu, a jego obniżony poziom wpłynie na skuteczniejsze oraz krótsze leczenie przeciwbólowe. 


\section{Podsumowanie}

Wielowymiarowy charakter przewlekłych zespołów bólowych powinien być leczony wielodyscyplinarnie, natomiast skuteczne jego zwalczanie będzie miało miejsce wówczas, gdy będziemy opierać się na zrozumieniu wszystkich komponentów składowych bólu takich jak jego anatomia, fizjologia czy też psychologia. Wówczas możemy prawidłowo ocenić stan funkcjonalny pacjenta.

Zwalczanie przewlekłych dolegliwości bólowych kręgosłupa uznane jako podstawowe prawo pacjenta powinno być leczone zarówno we właściwy sposób jak i we właściwym czasie.

W związku z wydłużającym się wiekiem społeczeństwa przybywa pacjentów z uciążliwymi objawami przewlekłego zespołu bólowego kręgosłupa. Ból jako czynnik ograniczający samodzielność jest ważnym elementem mającym wpływ na wydolność funkcjonalną pacjentów. Zasadne jest bowiem podejmowanie działań mających na celu monitorowanie i ocenę jego natężenia, jak również udział w czynnościach oraz zabiegach mających na celu wyeliminowanie, uśmierzenie lub chociażby zminimalizowanie tego przykrego doznania, czego konsekwencją jest poprawa jakości życia pacjentów. Zarówno skuteczność małoinwazyjnych zabiegów jak i profesjonalna opieka pielęgniarska odnajdują swoje uzasadnienie w zwalczaniu przewlekłych dolegliwości bólowych kręgosłupa.

\section{Bibliografia/Bibliography:}

1. Janiszewski R., Nowakowska A. Patomechanizm bólów krzyża. Medycyna Manualna 2001;1-2:10-13.

2. Żytkowski A., Sosnowski S., Wrodycka B. Etiopatogeneza choroby zwyrodnieniowej kręgosłupa. Polski Merkuriusz Lekarski. 2006;XXI(125): 498-501.

3. Wordliczek J., Dobrogowski J. Patofizjologia bólu pooperacyjnego. Przegl. Lek. 2000; 57:201-210.

4. Domżał T.M. Bóle krzyża. Przew. Lek. 2001;4:104-110.

5. Morton M. Zespoły bólowe kręgosłupa. Przew. Lek. 2008;11:45-52.

6. Ortenburger D., Stawiarska-Lietzau M. Psychologiczne i medyczne aspekty bólu oraz uwarunkowania jego terapii. WSP, Częstochowa 2000;377-386.

7. Krasuski M. Algorytm postępowania diagnostyczno-leczniczego w zespołach bólowych kręgosłupa. Rehabilitacja Medyczna 2005:9(3):19-25.

8. Wordliczek J., Dobrogowski J. Leczenie bólu. Wydawnictwa Lekarskie PZWL. Warszawa 2007;271-283. 
9. Dobrogowski J., Wordliczek J. Medycyna bólu. Wydawnictwo lekarskie PZWL. Warszawa 2004;283-293

10. Golec A, Dobrogowski J, Kocot M. Psychologiczne aspekty bólu pooperacyjnego. Przegl Lek $2000 ; 57$.

11. Dziak A. Bóle i dysfunkcje kręgosłupa. Medicina Sportiva. Kraków 2007; 403-414.

12. Styczyński T. Postępy w leczeniu choroby zwyrodnieniowej kręgosłupa. Reumatologia. 2013;51,6:429-436.

13. Malec-Milewska M., Kolęda I., Sękowska A., Kucia H., Kosson D.. Zastosowanie termolezji w leczeniu bólu przewlekłego opornego na farmakoterapię. Postępy Nauk Medycznych. 5/2014;317-322.

14. Raszka A., Waliszewska R., Sokal P., Zieliński P., Harat M. Quality of Life In Patients after Lumbar Thermolesion. The Journal of Neurological and Neurosurgical Nursing 2016:5(2);76-80.

15. Dobrogowski J. Niefarmakologiczne metody leczenia bólu. Polski Przegląd Neurologiczny 2007:3(4);272-278.

16. Waldman S.D. (red.). Pain management. Saunders Elsevier. Philadelphia 2006;1281-1293.

17. Sluijter M.E. Radiofrequency. Część 1. Flivo Press SA, Meggen 2001;105-171.

18. Przeklasa-Muszyńska A., Dobrogowski J., Wordliczek J. Estimation of therapeutic value of radiofrequency lesion of Gasserian ganglion with an addition of pentoxyphilline and methylprednisolone. Polska Medycyna Paliatywna. 2006:5(1);14-20.

19. Ruiz Lopez W.S.P., Erdine S. Treatment of craniofacial pain with radiofrequency procedures. Pain Practice. 2002;2:206-213.

20. Yoon K.B., Wiles J.R., Miles J.B., Nurmikko T.J. Long termoutcome of percutaneous thermocoagulation for trigeminal neuralgia. Anaesthesia 1999;54:803-808.

21. Świerkot J. Bóle krzyża - etiologia, diagnostyka i leczenie. Przew. Lek. 2006;9:86-98.

22. Ostrzyżek A. Jakość życia w chorobach przewlekłych. Problemy Higieny i Epidemiologii. 2008:89(4);467-470. 